\author{
DEPARTMENT OF THE INTERIOR \\ UNITED STATES GEOLOGICAL SURVEY
}

PREPARED IN PART IN COOPERATION WITH THE

COMMONWEALTH OF MASSACHUSETTS

DEPARTMENT OF PUBLIC WORKS

\title{
AEROMAGNETIC MAP OF THE ASHBY QUADRANGLE, MIDDLESEX AND WORCESTER COUNTIES, MASSACHUSETTS, AND HILLSBOROUGH COUNTY, NEW HAMPSHIRE
}

\author{
GEOPHYSICAL INVESTIGATIONS \\ MAP GP-730
}

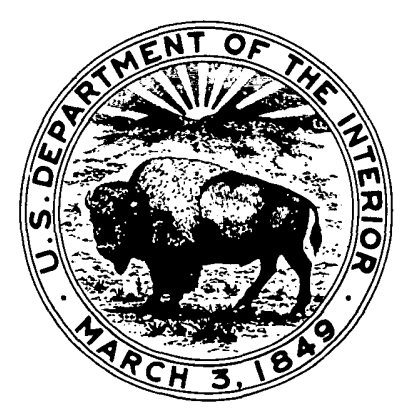

PUBLISHED BY THE U. S. GEOLOGICAL SURVEY WASHINGTON, D. C. 